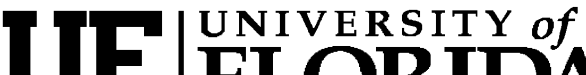 FLORIDA \\ IFAS Extension
}

\section{Getting the Most out of Bahiagrass Fertilization ${ }^{1}$}

\author{
C.L. Mackowiak, A.R. Blount, E.A. Hanlon, M.L. Silveira, M.B. Adjei, and R.O. Myer²
}

\section{Introduction}

Florida has about 5 million acres of improved pasture. Bahiagrass is the most adapted pasture grass in Florida. Some of its popularity is attributable to its ability to survive and even thrive where other grasses fail due to pests, drought, flooding, or low soil fertility. However, despite its adaptation, it still requires nutrients whether it is used for hay, sod, or in a pasture system. As with other grasses, bahiagrass can remove considerable quantities of nutrients from the soil (Table 1), which need to be replenished based on a soil test report and interpretation.

Table 1. Nutrient removal (Ibs per acre) by some forages grown for hay in Florida.

\begin{tabular}{|c|c|c|c|}
\hline Nutrient & $\begin{array}{l}\text { Bahiagrass } \\
\text { (5 tons/acre) }\end{array}$ & $\begin{array}{c}\text { Bernudagras } \\
\text { (5 tons/acre) }\end{array}$ & $\begin{array}{r}\text { Per. Peanut } \\
\text { (5 tons/acre) } \\
\end{array}$ \\
\hline \multicolumn{4}{|c|}{ 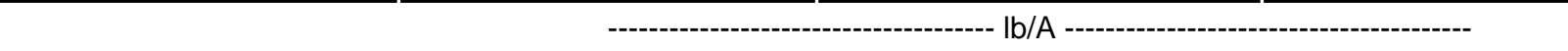 } \\
\hline Nitrogen (N) & 192 & 240 & $288^{*}$ \\
\hline Phosphate $\left(\mathrm{P}_{2} \mathrm{O}_{5}\right)$ & 53 & 60 & 55 \\
\hline Potash $\left(\mathrm{K}_{2} \mathrm{O}\right)$ & 223 & 240 & 229 \\
\hline Magnesium (Mg) & 24 & 23 & 54 \\
\hline Sulfur (S) & 19 & 26 & 18 \\
\hline Calcium (Ca) & 32 & 37 & 145 \\
\hline Manganese (Mn) & 1.5 & 0.8 & 1.3 \\
\hline Iron $(\mathrm{Fe})$ & 0.6 & 0.6 & 0.4 \\
\hline
\end{tabular}

1. This document is SL249, a fact sheet of the Soil and Water Science Department, Florida Cooperative Extension Service, Institute of Food and Agricultural Sciences, University of Florida. Publication date: April 2008. Please visit the EDIS Web site at http://edis.ifas.ufl.edu.

2. C.L. Mackowiak, assistant professor, Soil and Water Science, North Florida REC-Quincy, A.R. Blount, associate professor, Agronomy, and R.O. Myer, professor, Animal Science, North Florida REC-Marianna, E.A. Hanlon, professor, Soil and Water Science, Southwest Florida REC-Immokalee; M.L. Silveira, assistant professor, Soil and Water Science and M.B. Adjei (deceased), associate professor, Agronomy, Range Cattle REC-Ona, Florida Cooperative Extension Service, Institute of Food and Agricultural Sciences, University of Florida, Gainesville, FL 32611.

The Institute of Food and Agricultural Sciences (IFAS) is an Equal Opportunity Institution authorized to provide research, educational information and other services only to individuals and institutions that function with non-discrimination with respect to race, creed, color, religion, age, disability, sex, sexual orientation, marital status, national origin, political opinions or affiliations. U.S. Department of Agriculture, Cooperative Extension Service, University of Florida, IFAS, Florida A. \& M. University Cooperative Extension Program, and Boards of County Commissioners Cooperating. Larry Arrington, Dean 
Table 1. Nutrient removal (lbs per acre) by some forages grown for hay in Florida.

\begin{tabular}{|c|c|c|c|}
\hline Nutrient & $\begin{array}{l}\text { Bahiagrass } \\
\text { (5 tons/acre) }\end{array}$ & $\begin{array}{l}\text { Bernudagras } \\
\text { (5 tons/acre) } \\
\end{array}$ & $\begin{array}{r}\text { Per. Peanut } \\
\text { (5 tons/acre) }\end{array}$ \\
\hline & \multicolumn{3}{|c|}{------------------------- lb/A --------------------------- } \\
\hline Zinc $(\mathrm{Zn})$ & 0.31 & 0.27 & 0.23 \\
\hline Boron (B) & 0.04 & 0.04 & 0.28 \\
\hline Copper (Cu) & 0.07 & 0.06 & 0.04 \\
\hline
\end{tabular}

fertilizer options, including waste materials are available (Mackowiak et al., 2008). Additional management information can be found in the FDACS Cow-calf and Vegetable/Agronomic Crop BMP manuals, and the forage hay interim measure BMP recommendations( http://www.floridaagwaterpolicy.com).

\section{Soil Sufficiency Ranges}

Plant-available soil nutrients are determined using various acid extracting solutions, such as Mehlich-1 (also called "double-acid") or Mehlich-3. The soil fertilization recommendations provided by UF-IFAS are based on Mehlich-1 extractable nutrients (Tables $\underline{2}$ and $\underline{3}$ ). Use only the soil-test interpretation that matches your soil extraction method. Nitrogen fertilization recommendations are based on forage use (the University of Florida Extension Soil Testing Lab (ESTL) does not provide soil $\mathrm{N}$ analysis).

Table 2. Mehlich-1 soil nutrient interpretation ranges.

\begin{tabular}{|lccc|}
\hline \hline Soil Content & $\mathbf{P}$ & $\mathbf{K}$ & $\mathbf{M g}$ \\
\cline { 2 - 4 } & ---------- \\
Very Low & $<10$ & $<20$ & ---- \\
Low & $10-15$ & $20-35$ & $<15$ \\
medium & $16-30$ & $36-60$ & $15-30$ \\
High & $31-60$ & $61-125$ & $>30$ \\
Very High & $>60$ & $>125$ & ---- \\
\hline \hline
\end{tabular}

Soil micronutrient availability for proper bahiagrass growth throughout Florida is usually not a problem. However, a micronutrient soil test is available to detect potential deficiencies. Many soil micronutrient deficiencies can be offset by maintaining an appropriate soil $\mathrm{pH}$ regime for bahiagrass. Table 3 provides critical Mehlich- 1 soil test values for Florida agricultural lands.
Table 3. Critical low Mehlich-1 soil-test values for micronutrients.

\begin{tabular}{|cccc|}
\hline \hline Soil pH & Mn & Cu & Zn \\
\hline & ------ & 0.5 \\
$5.5-6.0$ & $3-5$ & $0.1-0.3$ & $0.5-1.0$ \\
$6.0-6.5$ & $5-7$ & $0.3-0.5$ & 0.5 \\
$6.5-7.0$ & $7-9$ & 0.5 & $1-3$ \\
\hline \hline
\end{tabular}

\section{Soil pH}

Regardless of soil type or bahiagrass use, maintaining a proper soil $\mathrm{pH}(5.5-6.5)$ is essential for adequate nutrient availability and uptake. If the soil is too alkaline, several micronutrient deficiencies may occur. If the soil is too acidic, sulfur and molybdenum (Mo) deficiencies may occur and manganese ( $\mathrm{Mn}$ ) may become toxic. The $\mathrm{pH}$ of some southern flatwoods soils can be 4.8 or lower, which can reduce forage yield. Additionally, if these highly acidic soils receive only $\mathrm{N}$, bahiagrass stand persistence may be compromised. For example, acidic soils in north Florida that received unbalanced $\mathrm{N}$ fertilization may have contributed to a dollar spot (Sclerotinia homoeocarpa) outbreak in 2001 (Blount et al., 2002) and mole cricket infestations (Adjei and Rechcigl, 2004). Fertilizer recommendations for bahiagrass are precluded by a soil liming recommendation when $\mathrm{pH}$ is 5.3 or lower in order to reach a target $\mathrm{pH}$ of 5.5. This ensures that there will be good fertilizer uptake by the plant.

Materials other than lime can influence soil $\mathrm{pH}$. Inorganic fertilizers containing ammonium $\left(\mathrm{NH}_{4}\right.$ will have some acidifying effect, while "lime stabilized" organic fertilizers, e.g., biosolids and litters, will provide a liming effect. Untreated manures and litters tend to have a slight to moderate acidifying effect. Let your soil analysis report be your guide to liming rates. In general, sandy soils (associated with 
flatwoods and the central Florida ridge) require less lime to raise soil $\mathrm{pH}$, and the change will be short-lived compared with liming a more loamy soil. Lime applied to pasture without mechanical incorporation rarely penetrates more than 2 or 3 inches into the soil over a year or two. If you frequently add lime, be sure that every few years you check the soil $\mathrm{pH}$ at the top 2 inches and compare with the lower 6 to 8 inches to verify that the top sample is within a range of $\mathrm{pH} 5.5$ to 6.5. This range helps avoid nutrient deficiencies, particularly in the spring when the soil is cool and bahiagrass shoot growth begins.

\section{Plant Tissue Nutrient Ranges}

Forage tissue along with soil can be used to diagnose and address a nutritional concern. IFAS recommendations for bahia fields with low soil $\mathrm{P}$ include forage sampling to verify $\mathrm{P}$ fertilization requirements (Mylavarapu et al., 2007). When sampling bahiagrass for tissue analysis, cut only actively growing plants and do not sample when dormant. Cut from 3 to 4 inches above the ground and from several places in your pasture and composite the sample. Be sure not to include any topsoil in your sample and avoid manure piles. Silveira et al. (2007) provides details on bahiagrass forage sampling. Additionally, your county extension agent may provide guidance on sampling technique and further explanation of the laboratory interpretation of tissue test results.

Table 4 provides suggested dry bahiagrass (above-ground) nutrient composition values for Florida. These values are guidelines based on forage yield and economic return. Table 4 will be periodically updated as we improve our understanding of bahiagrass nutritional requirements as they relate to forage use, varietal improvements, fertilizer sources, economic return and environmental protection.

Bahiagrass is prone to leaf yellowing (chlorosis) particularly in the spring and whenever leaf growth is rapid. This leaf yellowing is likely due to root uptake not keeping pace with plant micronutrient needs, particularly iron $(\mathrm{Fe})$. Yellowing often occurs in combination with cool soil temperatures. Maintaining the soil $\mathrm{pH}$ from 5.5 to 6.5 seems to minimize the problem.

Table 4. Plant tissue nutrient requirements (dry basis) for bahiagrass forage grown in Florida.

\begin{tabular}{|lc|}
\hline \hline Element & Sufficiency Range \\
\hline & $(\%)$ \\
Nitrogen (N) & $1.5-2.5$ \\
Phosphorus (P) & $0.15-0.35$ \\
Potassium (K) & $1.2-2.5$ \\
Magnesium (Mg) & $0.16-0.40$ \\
Sulfur (S) & $0.18-0.40$ \\
Calcium (Ca) & $0.3-1.0$ \\
& $(\mathrm{ppm})$ \\
Manganese (Mn) & $20-200$ \\
Iron (Fe) & $50-400$ \\
Zinc (Zn) & $20-100$ \\
Boron (B) & $5-50$ \\
Copper (Cu) & $4-20$ \\
\hline Molybdenum (Mo) & $0.1-4.0$ \\
\hline \hline
\end{tabular}

No reports have shown that leaf yellowing reduces forage yield, but in the case of sod, stand integrity may be compromised with time due to increased susceptibility to mole cricket damage. Iron and other micronutrients may be spray-applied to alleviate the chlorosis. A chelated iron source, plus a manganese (e.g. manganese sulfate) source, should be applied in spring and again in fall to correct any observed deficiencies (e.g. excessive yellowing).

\section{Establishment Fertilization}

Preplant fertilization of a clean-tilled seed bed is not encouraged since the risk of fertilizer loss is greater at that time compared with waiting until after emergence when the roots can take up the fertilizer. After emergence, apply $30 \mathrm{lbs}$ N/acre, all the recommended $\mathrm{P}_{2} \mathrm{O}_{5}$ rate, and $50 \%$ of the recommended $\mathrm{K}_{2} \mathrm{O}$ rate. After another month when the stand has established, apply the remaining $\mathrm{K}_{2} \mathrm{O}$ and $70 \mathrm{lbs} / \mathrm{acre}$ of $\mathrm{N}$.

\section{Grazing}

The current IFAS fertilization recommendations for Florida pastures provide for low, medium, or high $\mathrm{N}$ input systems. Bahiagrass fertilized with a low $\mathrm{N}$ option does not remove much P or K. Mineralized 
manure and urine supply additional nutrients, making it unnecessary to apply P or K for several years. Fertilizer applications (if required) should be made in spring to encourage plant nutrient uptake and rapid growth, which is especially important for cattle coming off winter pastures (Table 5). The low $\mathrm{N}$ option prevails with an optimum stocking rate of approximately 3 acres per cow. If higher stocking rates are used, then higher forage production (i.e. fertilization) may be needed to sustain the livestock.

A single hay cutting at the end of the growing season does not require any additional fertilizer after August. Omitting fertilization after August will ensure complete fertilizer utilization. If you cut hay once per season using the low or medium $\mathrm{N}$ input option, then follow the cutting with $80 \mathrm{lbs}$ N/acre and $50 \mathrm{lbs} \mathrm{K}_{2} \mathrm{O} / \mathrm{acre}$ if soil tests very low or low in $\mathrm{K}$. Apply $25 \mathrm{lb} /$ acre $\mathrm{P}_{2} \mathrm{O}_{5}$ if soil tests very low or low and tissue $\mathrm{P}<0.15 \%$. The high $\mathrm{N}$ option under grazing requires no additional $\mathrm{N}$ for a single hay cutting since ample $\mathrm{N}$ was supplied during the season. Apply $80 \mathrm{lb} /$ acre $\mathrm{K}_{2} \mathrm{O}$ if soil tests very low or low and $40 \mathrm{lb} / \mathrm{acre}$ if soil tests medium. Apply $40 \mathrm{lb} / \mathrm{A} \mathrm{P}_{2} \mathrm{O}_{5}$ if soil tests very low or low and tissue $\mathrm{P}<0.15 \%$.

Table 5. IFAS spring fertilizer recommendations for grazing.

\begin{tabular}{|c|c|c|c|}
\hline Fertilizer & $\begin{array}{l}\text { Low } \\
\text { Input }\end{array}$ & $\begin{array}{l}\text { Medium } \\
\text { Input }\end{array}$ & $\begin{array}{l}\text { High } \\
\text { Input }\end{array}$ \\
\hline & \multicolumn{3}{|c|}{ - } \\
\hline $\mathrm{N}$ & $50-60$ & 100 & $160^{\dagger}$ \\
\hline $\mathrm{K}_{2} \mathrm{O}$ & 0 & $50^{\ddagger}$ & $80^{\ddagger}$ \\
\hline $\mathrm{P}_{2} \mathrm{O}_{5}$ & $25^{\S}$ & $25^{\S}$ & $40^{\S}$ \\
\hline \multicolumn{4}{|c|}{$\begin{array}{l}{ }^{\dagger} \text { Split application (1/2 in early spring; } 1 / 2 \text { in } \\
\text { early summer). } \\
{ }^{\ddagger} \text { Split application and apply only if soil test } \\
\text { result is very low or low. } \\
{ }^{\S} \text { Apply only if soil test result is very low or low } \\
\text { AND forage tissue } P \text { is }<0.15 \% \text {. }\end{array}$} \\
\hline
\end{tabular}

There are other nutritional considerations when using bahiagrass in pastures as related to animal nutrition and health. It is recommended that bahiagrass tissue sulfur (S) be kept at or below $0.35 \%$. High forage $S$ can have a negative effect on copper $(\mathrm{Cu})$ availability in cattle.

\section{Hay/Silage}

For multiple hay cuts, apply $80 \mathrm{lbs}$ N/acre and recommended rates (based on soil test and tissue results) of $\mathrm{P}_{2} \mathrm{O}_{5}$ and $\mathrm{K}_{2} \mathrm{O}$ in spring. Apply $80 \mathrm{lbs} /$ acre $\mathrm{N}, 40$ lbs/acre $\mathrm{K}_{2} \mathrm{O}$, and 20 lbs/acre $\mathrm{P}_{2} \mathrm{O}_{5}$ (if soil $\mathrm{P}_{2} \mathrm{O}_{5}$ test was very low or low) following each cutting, except the final fall cut. Do not apply any fertilizer after mid-August.

As mentioned earlier, bahiagrass removes large quantities of nutrients per ton of forage (Table 1). The removed forage nutrients must be replaced, first from the soil and second from added fertilizer if the soil content is not sufficient. Knowing the fertility of your subsoil (below 8 inches) as well as your topsoil (0 to 8 inches) may help refine your fertilization program. Nitrogen, $P$, and $K$ tend to be in greatest concentration near the soil surface, but other nutrients like $\mathrm{S}, \mathrm{Mg}$, and some trace elements may be found in greater concentrations in the subsoil. Established perennial forages tend to have root systems that grow more than $4 \mathrm{ft}$ deep, and bahiagrass has a great mass of stoloniferous tissue to store nutrients. Therefore, bahiagrass tends to be more tolerant of low-fertility soils. However, fertilizing bahiagrass hay fields, particularly with $\mathrm{N}$, may increase yields by more than $50 \%$ compared with fields that are rarely fertilized.

\section{Seed Production}

For seed production in pastures, apply 60 to 80 lbs N/acre and soil-test "spring multiple hay cuts" recommended $\mathrm{P}$ and $\mathrm{K}$ fertilizer rates in February or March to provide for spring grazing. (hay fields do not require this late winter application.) When seed heads appear, remove cattle and apply another 60 to $80 \mathrm{lbs}$ N/acre. Hay fields with excessive dead grass may require burning in January or February and/or mowing through April. Apply 60 to $80 \mathrm{lbs}$ N/acre and soil-test recommended $\mathrm{P}$ and $\mathrm{K}$ rates before seed heads appear. Seed is usually ready for harvest in July for the Pensacola variety and August for the Argentine variety. After seed harvest, the remaining forage can be grazed or harvested. Ammonification of this hay can improve its nutritive value (Newman et al., 2007). 


\section{Sod}

In Florida, many bahiagrass pastures are harvested for sod or utility turf. As with any sod operation, fertilizer and seeding rates are generally higher compared with a pasture situation. Most of the following recommendations were taken from McCarty (1994): Apply $\mathrm{N}$ at 40 to 45 lbs/acre and $\mathrm{K}_{2} \mathrm{O}$ at 20 to $40 \mathrm{lbs} / \mathrm{acre}$ following the first hay cutting. The additional $\mathrm{K}_{2} \mathrm{O}$ may improve stress tolerance and promote better rooting of the turf. A subsequent fertilizer application should be made following the second cutting. Continue cutting and fertilizing every 4 to 6 weeks until the grass develops a full sod. Total seasonal $\mathrm{N}$ input should be on the order of 100 to $200 \mathrm{lbs} / \mathrm{acre}$. Post-sod removal fertilization rates depend upon removal strip size (from $1 \mathrm{ft}$ to the entire field) and reseeding rate (from $12 \mathrm{lbs} /$ acre to $200 \mathrm{lbs} / \mathrm{acre}$ ) (Chambliss, 2002; Trenholm et al., 2003).

\section{Silvopasture}

Bahiagrass is often a component of the agroforestry practice that combines trees, forage, and livestock, also known as silvopasture systems. The following fertilization recommendations are adapted from Tyree and Kunkle (2003): In general, current fertilizer recommendations for silvopasture are based on those for an open pasture. Bahiagrass establishment should follow the establishment recommendations mentioned above. After establishment, $\mathrm{N}$ and $\mathrm{K}_{2} \mathrm{O}$ fertilizers are split-applied according to IFAS bahiagrass pasture recommendations in spring and summer. Annual application rates of $100 \mathrm{lbs}$ N/acre N, $50 \mathrm{lbs}$ $\mathrm{P}_{2} \mathrm{O}_{5}$ /acre and $65 \mathrm{lbs} \mathrm{K}_{2} \mathrm{O} /$ acre provided the highest net returns from the system as a whole (forage, cattle and pines) (Tyree and Kunkle, 2003).

\section{Crop Rotation}

Bahiagrass has been introduced in a crop rotation to interrupt disease cycles and improve soil quality in cash crop systems (Katsvairo et al., 2006).

Establishment fertilization recommendations are the same as provided above. Additionally, if grazing will occur during the bahiagrass portion of the rotation, then the grazing fertility guidelines should be followed. If the bahiagrass will be used for hay, then the hay/seed recommendations should be followed. A well-managed bahiagrass rotation (including good fertility management) can provide disease and soil quality benefits to the succeeding cash crop in only 2 years. The benefits of a bahiagrass rotation might take longer to achieve if the grass is not properly managed or if managed or by using the low $\mathrm{N}$ input management option.

\section{Winter Overseeding}

Overseeding dormant bahiagrass pastures is a common practice for livestock operations. It provides grazing during the cool season, particularly in north Florida. The fertilization recommendations for winter forages are provided by Mylavarapu et al. (2007). A potential obstacle to good winter forage growth in a bahiagrass pasture is competition from bahiagrass for water and nutrients. Therefore, do not fertilize bahiagrass any later than late summer (approximately mid-August). Do not fertilize the winter forages until bahiagrass growth has stopped or slowed considerably. Since Argentine becomes dormant earlier than Pensacola or Tifton-9, it is the preferred sod for overseeding winter annuals. Overseeding with legumes can provide a source of $\mathrm{N}$ for the bahiagrass in the spring. The legume overseeding may be particularly beneficial for bahiagrass pastures receiving the low $\mathrm{N}$ input management option. Blount et al. (2007) provides winter forage recommendations for north Florida. The principal overseeding option for central and south Florida is annual ryegrass.

\section{Summer Legume Overseeding}

After a $30+$ year hiatus, interest in overseeding summer legumes into bahiagrass pastures is returning. Carpon desmodium and perennial peanut (perennials), and aeschynomene and hairy indigo (annuals) are among some of more popular pasture choices (Newman and Chambliss, 2007). Legumes seem to perform better in Pensacola or Tifton-9 pastures, which have less prostrate growth, than in Argentine. Fertilizer inputs should be limited to no more than $50 \mathrm{lb} / \mathrm{acre} \mathrm{N}$ to lessen grass competition with the legume. Further work is required by IFAS researchers to determine the best fertilization schedule for mixed pastures. 


\section{Recommended Reading}

Adjei, M. B., and J. E. Rechcigl. 2004. Interactive effect of lime and nitrogen on bahiagrass pasture. Soil and Crop Science Society of Florida Proceedings. 63:52-56.

Blount, A.R., R. D. Barnett, G. M. Prine, K. H. Quesenberry and Y.C. Newman. 2007. 2007 Fall forage update. EDIS publication SS-AGR-84 (http://edis.ifas.ufl.edu/AA266).

Blount, A.R., W. Dankers, M.T. Momol, and T.A. Kucharek. 2002. A severe outbreak of dollar spot (Sclerotinia homoeocarpa) on bahiagrass pastures in North Florida. EDIS publication SS-AGR-38 (http://edis.ifas.ufl.edu/AG145).

Chambliss, C.G. 2002. Forage planting and establishment methods. EDIS publication SS-AGR-161 (http://edis.ifas.ufl.edu/AG107).

Hanlon, E.A, R. Mylavarapu, I.V. Ezenwa. 2006. Development of Bahiagrass Fertilization Recommendations: 1990-2005. EDIA publication SL237 (http://edis.ifas.ufl.edu/SS456).

Katsvairo, T.W., D. L. Wright, J. J. Marois, D. Hartzog, P. J. Wiatrak, and J. R. Rich. 2006. Sod/livestock-based peanut/cotton production system: Why we recommend it! EDIS publication SS-AGR-126 (http://edis.ifas.ufl.edu/AG258).

Mackowiak, C.L., Mackowiak, J.B. Sartain, M.L. Silveira, E.A. Hanlon. 2008. Enhancing nitrogen fertilizer efficiencies in pastures. EDIS publication (in press).

McCarty, L.B. 2006. Sod production in Florida. EDIS publication 260 (http://edis.ifas.ufl.edu/LH066).

Mylavarapu, R., D. Wright, G. Kidder, and C.G. Chambliss. 2007. UF/IFAS standardized fertilization recommendations for agronomic crops. EDIS publication SL129 (http://edis.ifas.ufl.edu/SS163).

Newman, Y.C. and C.G. Chambliss. 2007. Warm season (summer) forage legume guide. EDIS publication SS-AGR-48 (http://edis.ifas.ufl.edu/DS126).
Newman, Y.C., C. Mackowiak, R. Mylavarapu, and M. Silveira. 2007. Fertilizing and liming forage crops. EDIS publication SS-AGR-76 (http://edis.ifas.ufl.edu/AG179).

Silveira, M.L., J.M. Vendramini, L. Sollenberger, C.L. Mackowiak, and Y. Newman. 2007. Tissue analysis as a nutrient management tool for bahiagrass pastures. EDIS publication SL252 (http://edis.ifas.ufl.edu/SS475).

Trenholm, L.E., J.L. Cisar, and J. Bryan Unruh. 2003. Bahiagrass for Florida Lawns. EDIS publication ENH6 (http://edis.ifas.ufl.edu/LH006).

Tyree, A.B., and W. E. Kunkle. 2003. Managing pine trees and bahiagrass for timber and cattle production. EDIS publication CIR1154 (http://edis.ifas.ufl.edu/AN023). 